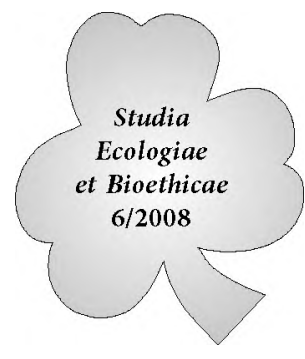

IEiB WFCh UKSW

\title{
Analiza wpływu budowy i eksploatacji infrastruktury drogowej na czynniki abiotyczne i biotyczne środowiska
}

\section{Wprowadzenie}

W dobie postępu cywilizacyjnego i poprawy warunków życia społeczeństwa, coraz większe znaczenie mają kwestie związane z ochroną środowiska naturalnego i krajobrazu. Liczni inżynierowie i naukowcy dyskutują nad nowoczesnymi rozwiązaniami technologicznymi w różnych dziedzinach przemysłu, a dyrektywy unijne i międzynarodowe ratyfikowane przez Polskę wyznaczają proekologiczny kierunek działań w wielu aspektach rozwoju.

Przejawem dobrobytu społecznego panującego w Europie jest rozwój gałęzi gospodarki, związanych $z$ rozbudową infrastruktury drogowej, w szczególności autostrad i dróg ekspresowych. Niewielka część społeczeństwa zdaje sobie jednak sprawę z tego, że drogi szybkiego ruchu są jedną z form drastycznej ingerencji w układy ekologiczne i krajobraz. Kierowcy z zadowoleniem przyjmują wiadomości o kolejnych kilometrach tras oddanych do użytku, domagając się coraz szybszego wybudowania kolejnych. Nie zastanawiają się jednak nad kosztami, jakie ponosi środowisko naturalne, a tym samym nasze i przyszłe pokolenia. Faktem jest, że tranzytowe położenie naszego kraju wymaga poprawy stanu technicznego i wybudowania nowych szlaków komunikacyjnych, aby upłynnić transport międzynarodowy pomiędzy Europą Zachodnią a państwami azjatyckimi oraz południem Europy i krajami skandynawskimi. Odpowiednie połączenia międzyregionalne zapewnią spójność terytorialną kraju oraz umożliwią pełne wykorzystanie potencjału gospodarczego Polski. Stworzenie sieci drogowej o odpowiednich parametrach technicznych i większej przepustowości ma stanowić nadrzędny cel Polityki Øransportowej na najbliższe lata. Jednak wyasfaltowany krajobraz wielu państw Europy Zachodniej nie powinien być dla nas przykładem do naśladowania. 
Budowa nowych oraz eksploatacja już istniejących dróg, są w wysokim stopniu uciążliwe dla człowieka i środowiska przyrodniczego. Negatywne oddziaływania występują nie tylko w bezpośrednim otoczeniu drogi, część z nich ma działanie transgraniczne. Budowa drogi powoduje trwałe zajęcie terenu pod planowaną trasę, czasowe zajęcie pod drogi dojazdowe do budowy, składy na materiały i maszyny, miejsca poboru kruszyw $i$ inne. $Z$ terenów tych usuwana jest roślinność i warstwy gleby, giną drobne zwierzęta, przekształcona zostaje rzeźba terenu oraz stosunki wodne. Zniszczeniu ulegają dobra kultury ukryte w ziemi. Szlaki komunikacyjne wpływają na rozmieszczenie siedlisk fauny i flory, zmieniają mikroklimat okolicznych terenów i zanieczyszczają środowisko. Również masowe użytkowanie pojazdów powoduje wielostronne, negatywne oddziaływanie na środowisko, związane z obciążeniem zanieczyszczeniami atmosfery i środowiska gruntowo-wodnego, wzrostem hałasu oraz barierami na trasach migracji zwierząt. Nie można także zapomnieć o ostatnio niekontrolowanym imporcie do Polski używanych samochodów, przekraczających często unijne normy. Rozwój i ekspansja przemysłu motoryzacyjnego nie liczy się z konsekwencjami i ofiarami po stronie natury. Istotne zatem, staje się pogodzenie potrzeb człowieka $z$ szeroko pojętą ochroną środowiska naturalnego.

\section{Zanieczyszczenie powietrza atmosferycznego}

Pojazdy samochodowe stanowią w ostatnich latach jedno z największych źródeł toksycznych zanieczyszczeń, obciążając atmosferę zanieczyszczeniami powstającymi podczas spalania paliw w silnikach. Udział transportu samochodowego w ogólnej emisji zanieczyszczeń do atmosfery jest bardzo wysoki i dochodzi w niektórych krajach do $50 \%$ i więcej. Stosowane obecnie paliwa są mieszaniną odpowiednio dobranych, ciekłych węglowodorów. Dąży się też do uzyskania jak największej ilości energii poprzez całkowite i zupełne spalenie paliw do $\mathrm{CO}_{2}$ $\mathrm{i}_{2} \mathrm{O}$. Jednak w rzeczywistości idealne spalenie jest praktycznie niemożliwe niektóre cząsteczki węglowodorów, podczas procesu spalania, przekształcają się $\mathrm{w}$ aktywne rodniki, a te reagując $\mathrm{z}$ tlenem tworzą produkty utleniania (np. tlenek węgla, aldehydy i inne pochodne tlenowe). Do tego należy dodać również zbyt krótki czas przebywania paliwa w cylindrze silnika. Emisja zanieczyszczeń pochodzących z komunikacji miejskiej sprawia wiele problemów - jest ona rozproszona i tym samym trudna do opanowania, zanieczyszczenia emitowane są nisko (w strefie bytowania istot żywych) i w połączeniu z niesprzyjającymi warunkami atmosferycznymi (wilgoć, wysoka temperatura, minimalne ruchy mas powietrza, duże nasłonecznienie) powoduje niebezpieczny smog.

W gazach emitowanych $\mathrm{z}$ silników pojazdów podczas procesu spalania znajduje się wiele toksycznych związków. Ich zawartość zależy od wielu czynników: typu silnika spalinowego, rodzaju i składu paliwa, rozwiązań konstrukcyjnych sil- 
nika i sposobu przygotowania mieszanki oraz warunków pracy silnika. Składniki toksyczne dla środowiska stanowią jedynie 1,1\%, ale biorąc pod uwagę ilość pojazdów na całym świecie - wielkość emisji jest bardzo duża.

Azot zawarty w powietrzu uczestniczy w reakcji spalania paliw tworząc tlenki azotu ( $\mathrm{NO}-95 \%, \mathrm{NO}_{2}$ i $\mathrm{N}_{2} \mathrm{O}$ ). Biorą one udział w wielu reakcjach chemicznych zachodzących w atmosferze. W porze nocnej powstają rodniki azotanowe $\mathrm{NO}_{3}$ (najaktywniejsze utleniacze), a w zanieczyszczonym powietrzu tworzy się $\mathrm{N}_{2} \mathrm{O}_{5}$, który wchodząc w reakcje $\mathrm{z}$ wodą, tworzy kwas azotowy $\left(\mathrm{HNO}_{3}\right)$, będący przyczyną późniejszych kwaśnych deszczy. Đlenki azotu naruszają również równowagę atmosfery poprzez rozpad ozonu i powoduje powstawanie dziury ozonowej.

Związki azotu działają na organizm człowieka bardzo toksycznie - obniżają zdolność krwi do transportu tlenu (a w konsekwencji powodują niedotlenienie organizmu), są przyczyną rozwoju nowotworów, osłabiają układ immunobiologiczny, powodują zaburzenia w oddychaniu, astmę i choroby alergiczne.

Z punktu widzenia wymagań układów: zasilania i spalania, korzystne właściwości wykazują węglowodory izoparafinowe i aromatyczne. Niemniej jednak, najprostszy aren, jakim jest benzen $\left(\mathrm{C}_{6} \mathrm{H}_{6}\right.$, o liczbie oktanowej 97$)$ jest substancją toksyczną i posiada właściwości kancerogenne, natomiast podczas niezupełnego spalania wydziela nadmierne ilaści koksu i sadzy, dlatego jego obecność jest w dużym stopniu ograniczana, a nawet eliminowana. W procesie spalania, przy niedoborze tlenu, węglowodory zawarte w mieszance paliwowej ulegać mogą częściowym procesom krakingu, pirolizy, koksowania (prowadząc do powstania węglowodorów olefinowych) i dalej polimeryzacji i cyklizacji (tworząc wielopierścieniowe węglowodory aromatyczne WWA - np. wysoce rakotwórczy benzo(a)piren). Udział transportu w ogólnej emisji WWA jest największy i wynosi 45\% (reszta pochodzi z emisji napływowej - 15\%, tzw. niskiej emisji, czyli kominów domów jednorodzinnych - 35\% i tzw. emisji wysokiej, czyli przemysłu - 5\%).

Stwierdzona jest również obecność tych związków w masach bitumicznych (asfaltach, stosowanych do budowy nawierzchni drogowych), będących produktami przeróbki ropy naftowej. Zawierają one głównie węglowodory pierścieniowe aromatyczne i/lub naftenowe oraz nasycone. Badania przeprowadzone na zwierzętach wykazały, że asfalty zwiększają ryzyko występowania nowotworów skóry i płuc, natomiast przy produkcji asfaltów i robotach drogowych pracownicy są narażeni na działanie toksycznych substancji wchodzących w skład mieszanek bitumicznych. Prowadzone analizy wykazały w dymach asfaltów obecność trzynastu WWA - fenantrenu, antracenu, fluorantenu, pirenu, chryzenu, benzo(a)antracenu, perylenu, benzo(a)pirenu, benzo(e)pirenu, benzo(g,h,i)perylenu, dibenzopirenu, koronenu, antracenu, we frakcji dymów asfaltów rozpuszczalnej w benzenie, $\mathrm{z}$ czego benzo(a)piren występuje na poziomie od 0,004 do $1,3 \mathrm{mg} / \mathrm{m}^{3}$. Podczas produkcji mas stosowanych do budowy nawierzchni dróg, jak również podczas wykonywania robót, asfalty są poddawane działaniu wysokich tempera- 
tur od $130^{\circ} \mathrm{C}$ do $250^{\circ} \mathrm{C}$ w celu ich uplastycznienia i upłynnienia. Wydzielają się wtedy dymy, które są złożonymi mieszaninami szkodliwych substancji o różnym charakterze chemicznym i różnym stopniu toksyczności. Stanowią one zagrożenie dla zdrowia pracowników, głównie ze względu na możliwość występowania wielopierścieniowych węglowodorów aromatycznych (WWA). Zwiększa to prawdopodobieństwo ich narażenia na związki rakotwórcze.

Emisja wielopierścieniowych węglowodorów aromatycznych w wyniku rozwoju motoryzacji na tak szeroką skalę, prowadzi do skażenia wszystkich elementów środowiska. Ma silne działanie toksyczne na człowieka, wywołując ostre i przewlekłe zatrucia oraz charakteryzując się właściwościami rakotwórczymi.

Siarka w atmosferze występuje w postaci ditlenku siarki $\left(\mathrm{SO}_{2}\right)$, który wchodząc w reakcje z parą wodną, tworzy kwas siarkowy (IV) i opada w postaci kwaśnego deszczu. Kwaśne deszcze są potoczną nazwą całego szeregu zjawisk atmosferycznych, powstających w reakcji zanieczyszczeń $z$ wodą. Przybierają one postać deszczu, śniegu, gradu lub mgły i mają oddziaływanie transgraniczne. Kwaśny opad zmienia chemizm gleby, powodując utratę przez rośliny chlorofilu. Hamuje to przebieg fotosyntezy, a w konsekwencji wywołuje obumieranie roślin. Ditlenek siarki atakuje u człowieka drogi oddechowe, powodując skurcze i nieżyty oskrzeli. Po wniknięciu do organizmu, przenika do krwi, kumulując się w śledzionie, wątrobie, mózgu i węzłach chłonnych a nawet może doprowadzić do zmian w gałce ocznej. Kwaśny opad w postaci mgły jest przyczyną powstawania smogu miejskiego (inaczej siarkowego) w dużych aglomeracjach. Obserwuje się wtedy zwiększoną umieralność noworodków, gdyż delikatne tkanki płucne nie wytrzymują tak dużych stężeń zanieczyszczeń siarkowych (zjawisko to nosi nazwę „niespodziewana śmierć niemowląt”).

Źródłem tlenków siarki w powietrzu są: po pierwsze - procesy utleniania siarki zawartej w paliwach podczas spalania w silniku samochodowym, po drugie - związki siarki zasysane wraz z powietrzem do komory spalania w silniku. Ze względu na ich toksyczne i korozyjne działanie, ograniczono zawartość siarki w paliwach płynnych, używanych w transporcie, natomiast nadal jest ona dość wysoka w paliwach ciepłowniczych i stałych. Obecne wymogi, dotyczące ochrony powietrza atmosferycznego, zmuszają do poszukiwania skutecznych technologii odsiarczania paliw, w celu ograniczenia jej zawartości do minimum.

\lenek węgla (CO) powstaje na skutek niecałkowitego spalenia praktycznie we wszystkich procesach spalania. Jest gazem silnie toksycznym, ale mała gęstość $\left(1,25 \mathrm{~kg} / \mathrm{m}^{3}\right)$ umożliwia jego szybkie rozprzestrzenienie się w powietrzu. $\mathrm{W}$ atmosferze tlenek węgla utlenia się do ditlenku węgla $\left(\mathrm{CO}_{2}\right)$, który nie jest uznany za gaz toksyczny, ale ogromne ilości emitowane do atmosfery, przyczyniają się do jego koncentracji, podniesienia temperatury na ziemi i spotęgowania efektu cieplarnianego. Może to wywołać negatywne skutki dla środowiska naturalnego. Dotychczas oddziałuje on w niewielkim stopniu na florę, natomiast 
szczególnie toksycznie wpływa na człowieka i zwierzęta - łączy się trwale z hemoglobiną, co uniemożliwia transport tlenu przez krew, powodując w konsekwencji niedotlenienie i obumieranie tkanek. Zbyt duże ilości tlenku węgla i ditlenku węgla notowane są na terenach wielkich aglomeracji, ale wraz z ruchami mas powietrza, rozprzestrzenia się on transgranicznie na dalekie odległości. W Polsce największe stężenia tlenków węgla występują na terenach województwa śląskiego i małopolskiego.

Negatywny wpływ na środowiska naturalne mają również metale ciężkie (ołów, kadm, rtęć) i pyły zawieszone, powstające podczas spalania paliw w silnikach samochodowych. Jeszcze niedawno paliwa zawierały znaczące ilości ołowiu w postaci tetraetyloołowiu $\left[\left(\mathrm{C}_{2} \mathrm{H}_{5}\right)_{4} \mathrm{~Pb}\right]$, przez co - przy spalaniu 1 litra paliwa - ulatywało w powietrze $200-400 \mathrm{mg}$ ołowiu w postaci lotnych halogenków . Obecnie, ze względu na ochronę środowiska i wciąż zwiększającą się liczbę samochodów, paliwa ołowiowe wycofano z eksploatacji, zastępując je paliwami bezołowiowymi. \ransport jest również odpowiedzialny za ok. 37\% całkowitej emisji pyłu zawieszonego, z czego znaczna część pochodzi z procesów innych niż spalanie paliw, mianowicie ścieranie opon i hamulców czy ścieranie nawierzchni dróg ${ }^{1}$.

Ozon przygruntowy natomiast jest wynikiem skomplikowanej reakcji fotochemicznej ozonu (złożonego z trzech atomów tlenu) z tlenkami azotu, tlenkiem węgla i węglowodorów (pochodzących ze spalin samochodowych), przy udziale energii słonecznej. Szkodliwe działanic ozonu jest wynikiem nietrwałego trzeciego atomu tlenu, który w dolnych częściach atmosfery łatwo uwalnia się, jako reaktywny wolny rodnik i szybko reaguje z substancjami zanieczyszczającymi. Ostatnie badania wykazują, że ozon przygruntowy (inaczej zwany też smogiem fotochemicznym) jest bardzo szkodliwy dla organizmów żywych. Uszkadza rośliny, wnikając do wnętrza tkanek liści przez aparaty szparkowe, które w konsekwencji bardziej się rozszerzają, przez co kwaśny opad może łatwiej dostać się do wnętrza rośliny, wypłukać składniki odżywcze i zakłócić proces fotosyntezy oraz funkcje metaboliczne. U ludzi działa negatywnie na układ oddechowy - przenika do płuc, powodując obrzęki, rozedmy astmy, alergie. W większych stężeniach powoduje zapalenie spojówek, bóle głowy, raka płuc, może nawet prowadzić do zgonu. Ozon ma także niszczące działanie na materiały organiczne i nieorganiczne, przyspieszając korozję i degradację; uszkadza gumę, farby i tworzywa sztuczne.

http://www.europarl.europa.eu/news/public/story_page/064-11035-268-09-39-911-20060927S®O11034-2006-25-09-2006/default_pl.htm 


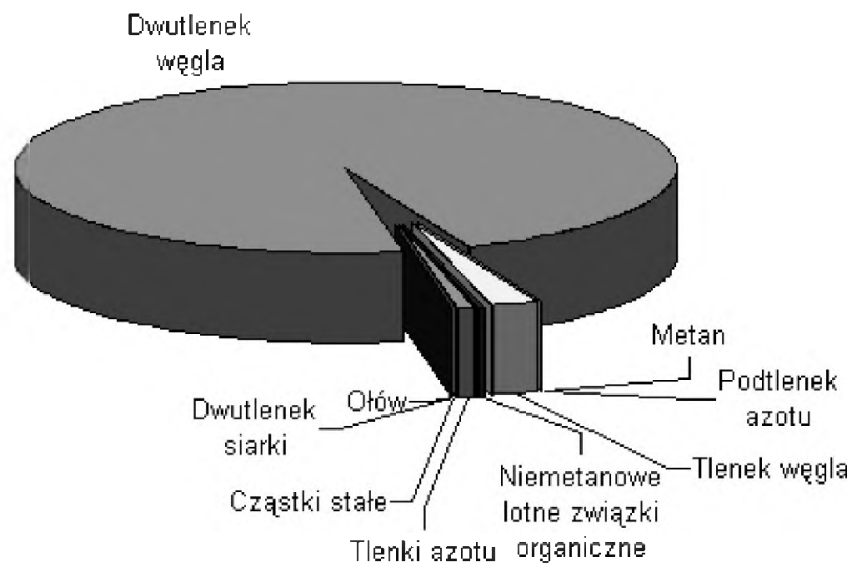

Rys. 1. Poziom emisji podstawowych zanieczyszczeń powietrza, pochodzacych $z$ transportu drogowego w Polsce (stan $z 2003$ roku)

Według Polityki Klimatycznej Polski, rząd powinien położyć nacisk na restrukturyzację sektorów gospodarczych w kierunku dywersyfikacji paliw, co ograniczyłoby emisję zanieczyszczeń powietrza.

Określenie ujemnego wpływu zanieczyszczeń powietrza, powstających podczas budowy i eksploatacji infrastruktury drogowej, zależy od wieku, płci, indywidualnej odporności organizmu, warunków klimatycznych, stężenia i czasu oddziaływania zanieczyszczeń. Okazuje się jednak, że spaliny samochodowe są dużo bardziej szkodliwe dla człowieka, niż zanieczyszczenia pochodzące z przemysłu, ze względu na rozprzestrzenianie się ich w dużych stężeniach, na niewielkich wysokościach i w bliskim sąsiedztwie ludzi.

Tabela 1. Wplyw najważniejszych zanieczyszczeń powietrza na zdrowie czlowieka

\begin{tabular}{|l|l|}
\hline Substancja zanieczyszczająca & \multicolumn{1}{c|}{ Wpływ na zdrowie człowieka } \\
\hline Ditlenek siarki $\left(\mathrm{SO}_{2}\right)$ & $\begin{array}{l}\text { Szczególnie groźny dla astmatyków, przyczynia się do płytkiego } \\
\text { świszczącego oddechu. Atakuje struny głosowe. Niszczy układ } \\
\text { oddechowy, powodując skurcze i nieżyty oskrzeli. Dłuższe } \\
\text { narażenie może prowadzić do przewlekłych chorób płuc, } \\
\text { a nawet do śmierci. Może prowadzić do zmian w rogówce oka. } \\
\text { Kumuluje się w ściankach tchawicy i oskrzelach oraz wątrobie, } \\
\text { śledzionie, mózgu i węzłach chłonnych, zaburzając ich funkcjo- } \\
\text { nowanie. }\end{array}$ \\
\hline
\end{tabular}

2 http://ec.europa.eu/environment/youth/air/air_effects_pl.html 


\begin{tabular}{|c|c|}
\hline Ditlenek azotu $\left(\mathrm{NO}_{2}\right)$ & $\begin{array}{l}\text { Początkowo następuje spowolnienie przepływu krwi i hamuje } \\
\text { proces uwalniania tlenu obecnego w czerwonych krwinkach. } \\
\text { Hamuje proces przenoszenia tlenu przez krew } \\
\text { i w konsekwencji prowadzi do niedotlenienia organizmu. } \\
\text { Obciąża zdolności obronne organizmu na infekcje bakteryj- } \\
\text { ne. Działa drażniąco na oczy, powoduje choroby alergiczne. } \\
\text { Dłuższy czas narażenia źle wpływa na funkcjonowanie wątroby, } \\
\text { śledziony, płuc i pracę serca. Zarówno NO, jak i } \mathrm{NO}_{2} \text { są prekur- } \\
\text { sorami powstających w glebie rakotwórczych i mutagennych } \\
\text { nitrozoamin. }\end{array}$ \\
\hline 冈lenek węgla (CO) & $\begin{array}{l}\text { Krótkie narażenia powoduje spowolnienie przepływu krwi } \\
\text { i hamuje proces uwalniania tlenu obecnego w czerwonych } \\
\text { krwinkach. Następują bóle i zawroty głowy, oszołomienie, } \\
\text { duszności, wymioty, przyśpieszony oddech i kołatanie serca, } \\
\text { a w końcu utrata przytomności. Przy dłuższym narażeniu, CO } \\
\text { łączy się trwale z hemoglobiną, co hamuje proces przenoszenia } \\
\text { tlenu przez krew i w konsekwencji prowadzi do niedotlenienia } \\
\text { organizmu(szczególnie mózgu i serca). Długie działanie powo- } \\
\text { duje ciężkie zatrucia, prowadząc do chorób sercowo-naczynio- } \\
\text { wych lub do śmierci. }\end{array}$ \\
\hline Ołów (Pb) & $\begin{array}{l}\text { Hamuje syntezę witaminy D, uszkadza centralny układ nerwo- } \\
\text { wy, powoduje pogorszenie pracy mózgu, nawet uszkadza słuch. } \\
\text { Gromadząc się w kościach, wątrobie i nerkach, zaburza ich } \\
\text { funkcjonowanie. Szkodliwie działa na układ nerwowy. Może } \\
\text { przyczynić się do bezpłodności. } \\
\text { W połączeniu z ozonem stanowi poważne zagrożenie dla } \\
\text { zdrowia czlowieka. }\end{array}$ \\
\hline Pyły & $\begin{array}{l}\text { Najbardziej niebezpieczne, najmniejsze cząstki pyłów, latwo } \\
\text { przenikają do organizmu, osiadając na ściankach pęcherzyków } \\
\text { płucnych i utrudniając wymianę gazowa w płucach. Powodują } \\
\text { podrażnienie naskórka i śluzówki, zapalenia górnych dróg } \\
\text { oddechowych; wywołują choroby oczu, choroby alergiczne, } \\
\text { astmę a także ciężkie schorzenia, jak pylica płuc oraz nowotwo- } \\
\text { ry płuc, gardła, krtani. }\end{array}$ \\
\hline $\begin{array}{l}\text { Ozon }\left(\mathrm{O}_{3}\right) \text { i inne utleniacze } \\
\text { fotochemiczne }\end{array}$ & $\begin{array}{l}\text { Jest szkodliwy dla płuc i powoduje zapalenie dróg odde- } \\
\text { chowych, nasilający się kaszel, a także groźne ataki astmy. } \\
\text { Wystawienie na utleniacze fotochemiczne (zanieczyszczenia } \\
\text { powstające w wyniku reakcji chemicznych zachodzących pod } \\
\text { wpływem promieniowania słonecznego w powietrzu zanie- } \\
\text { czyszczonym tlenkami azotu i węglowodorami) prowadzi } \\
\text { u zwierząt do infekcji bakteryjnych w płucach, zapalenia ukła- } \\
\text { du oddechowego oraz do zmian kształtu płuc. }\end{array}$ \\
\hline WWA & $\begin{array}{l}\text { Wywołują ostre i przewlekłe zatrucia. Większość z nich ma } \\
\text { właściwości rakotwórcze. }\end{array}$ \\
\hline
\end{tabular}

Europa jest jednym z największych "udziałowców” globalnego zanieczyszczenia powietrza salinami samochodowymi, ze względu na swoją wielkość, liczbę mieszkańców i poziom rozwoju cywilizacyjnego. Z tego też względu Unia 
Europejska czuje się odpowiedzialna za ograniczanie ich emisji do atmosfery i od lat wprowadzane są wymogi oraz nowe przepisy - dotyczące obniżania wysokiego poziomu stężeń niektórych substancji - do których państwa członkowskie mają obowiązek się dostosować.

\section{Hałas i wibracje}

Intensywny rozwój urbanizacji i techniki, jaki obserwujemy w ostatnich latach powoduje powstawanie coraz większej ilości niekorzystnych zjawisk, pogarszających warunki środowiska, w którym żyjemy. Ustawa z dnia 27 kwietnia 2001 r. Prawo Ochrony Środowiska (Dz. U. Nr 62, poz. 627; ze zmianami) definiuje hałas jako dźwięki o częstotliwościach od $16 \mathrm{~Hz}$ do $16000 \mathrm{~Hz}$. Zwyczajowo określa się nim każdy dźwięk, który w danych warunkach uznawany jest za szkodliwy, uciążliwy lub przeszkadzający, działający za pośrednictwem powietrza na organ słuchu i inne zmysły oraz elementy żywego organizmu. W zależności od częstotliwości drgań wyróżnia się:

- hałas infradźwiękowy (niesłyszalny, lecz odczuwalny) o częstotliwości drgań poniżej $20 \mathrm{~Hz}$;

- hałas słyszalny o częstotliwości w przedziale $20-20000 \mathrm{~Hz}$;

- hałas ultradźwiękowy (niesłyszalny) ponad $20000 \mathrm{~Hz}$.

Natomiast określenie „wibracje” dotyczy drgań oddziałujących na organizm, nie za pośrednictwem powietrza, lecz ciał stałych.

Jeśli chodzi o klasyfikację źródeł hałasu i wibracji to wyróżnia się: źródła pojedyncze (np. środki komunikacji i transportu) i źródła zgrupowane na określonej przestrzeni (np. drogi, lotniska, zajezdnie, dworce).

Dominujący wpływ na klimat akustyczny ma hałas komunikacyjny, zarówno podczas budowy jak i eksploatacji infrastruktury drogowej. Przykładowe poziomy dźwięku emitowanego do środowiska przyrodniczego przedstawiają się następująco:

- pojazdy jednośladowe 79-87 dB;

- samochody ciężarowe 83-93 dB;

- autobusy i ciągniki $85-92 \mathrm{~dB}$;

- samochody osobowe 75-84 dB;

- maszyny drogowe i budowlane 75-85 dB;

- wozy oczyszczania miasta 77-95 $\mathrm{dB}^{3}$.

Wartości te przekraczają znacznie dopuszczalne poziomy hałasu, które zgodnie z wymaganiami, określonymi przez polską normę powinny wynosić maksymalnie 45-60 dB. Powoduje to pogorszenie jakości środowiska, poprzez: zakłócanie ciszy, obniżenie lub utratę wartości terenów rekreacyjno-wypoczynkowych

3 http://mos.gov.pl/1materialy_informacyjne/archiwum/soe_pl/12c.htm 
i leczniczych oraz często obserwowane zmiany zachowań ptaków i innych zwierząt (stany lękowe, zmiany lokalizacji siedlisk, spadek liczby potomstwa).

Szacuje się, że w Polsce około 17 \% terenów jest zagrożonych ponadnormatywnym hałasem, powodowanym przez komunikację drogową, a w ostatnich latach obserwuje się znaczny wzrost motoryzacji (nasilający się z każdym rokiem). Wynika to $\mathrm{z}$ gwałtownego rozwoju gospodarczego, jaki następuje w związku z przystąpieniem Polski do Unii Europejskiej. Wzrasta zapotrzebowanie na przewozy drogowe, powodujące zatłoczenie na drogach krajowych i terenach większych miast, i w konsekwencji pogorszenie stanu akustycznego środowiska.

Hałas i wibracje, uznane również za zanieczyszczenia, charakteryzują się obecnie mnogością źródeł i powszechnością występowania. „Świadczy o tym fakt, że hałas o ponadnormatywnym poziomie obejmuje $21 \%$ powierzchni kraju, oddziałując na jedną trzecią ludności”" Ponieważ odbiór wrażeń hałasowych jest indywidualny, często ich negatywny wpływ na człowieka jest bagatelizowany tym bardziej, że skutki oddziaływania nie są widoczne natychmiast.

Do powszechnie występujących następstw hałasu i wibracji należą:

- obniżenie sprawności fizycznej i uczenia oraz wydajności pracy;

- negatywny wpływ na komunikację międzyludzką;

- utrudniony odbiór sygnałów optycznych;

- powstawanie częstych napięć i kłótni spowodowanych podrażnieniem układu nerwowego i drażliwością;

- brak koncentracji uwagi, bóle głowy i w konsekwencji wypadki;

- wzrost nadpobudliwości nerwowej (już przy natężeniu $55 \mathrm{~dB}$ ), destrukcja układu nerwowego i psychiczna niemoc bądź agresja (dwie skrajności); uważa się, że poniżej $55 \mathrm{~dB}$ oddziaływanie hałasu nie stwarza problemów

- pogorszenie funkcjonowania układu immunologicznego;

- zaburzenie rytmu oddychania;

- wzrost ciśnienia tętniczego krwi;

- gwałtownie rosnąca liczba zachorowań na głuchotę i chorobę wibracyjną oraz związane z tym koszty leczenia, renty inwalidzkie;

- niezauważalne zmiany akcji mięśnia sercowego oraz w konsekwencji zwiększająca się liczba występowania zawałów serca (przy natężeniu 60-75 dB);

- częste zakłócenia snu i bezsenność;

- przemęczenie organizmu i apatia;

- zbyt wczesne starzenie się (nawet o 8-12 lat);

- zaburzenia kształtowania i rozwoju umysłowego dzieci poprzez brak koncentracji.

Hałas jest dziś problemem większości krajów rozwiniętych, a zagrożenie hałasem w Polsce jest większe niż w innych krajach Unii Europejskiej i stale wzra-

4 http://www.euro-net.pl/ adamczak/ekologia/wibracje.htm 
sta. Powszechnie uważa się, że natężenie hałasu poniżej $55 \mathrm{~dB}$ nie powoduje problemów ze zdrowiem, natomiast wraz ze wzrostem poziomu staje się coraz bardziej odczuwalne. Niekorzystne działanie występuje przy natężeniu $65 \mathrm{~dB}$.

Według profesora Henryka Skarżyńskiego (dyrektora Międzynarodowego Centrum Słuchu i Mowy Instytutu Fizjologii i Patologii Słuchu w Kajetanach k. Warszawy) "co trzecia osoba dorosła ma problemy ze słuchem w życiu codziennym i co piąte dziecko $w$ wieku szkolnym między 6 a 19 rokiem życia. Jeżeli zdamy sobie sprawę, że co drugi uczeń w szkole średniej miewa przemijające szumy uszne, to oznacza to, że już w tym wieku zaczynają się problemy ze słuchem, których jeszcze nie odczuwa w codziennych kontaktach z otoczeniem. Ale oznacza to, że w wieku 30 - 40 lat, obecne pokolenie młodzieży będzie miało słuch 60-latków."

Według Światowej Organizacji Zdrowia, długotrwałe narażanie się na hałas o natężeniu przekraczającym $85 \mathrm{~dB}$ może prowadzić do zupełnej utraty słuchu.

Wraz ze wzrostem ruchu samochodowego rośnie zagrożenie dla życia zwierząt, które zamieszkują tereny w pobliżu dróg i autostrad. Hałas komunikacyjny nie wywołuje trwałych zmian w organizmach, ale jest dla nich uciążliwy i może powodować trwałe skutki zdrowotne. Dla zwierząt utrata przez środowisko naturalne wartości, jaką jest cisza, ma znaczenie podstawowe. Środki ochrony biernej przed hałasem, czyli budowa ciągów ekranów akustycznych, wałów ziemnych czy tuneli, stanowi dla nich bariery, często nie do pokonania, oraz zmienia kierunki ich szlaków migracyjnych. Proces migracji zostaje wtedy zahamowany, czego skutkiem jest ograniczenie możliwości doskonalenia i wymiany materiału genetycznego. Hałas drogowy może także odciąć płochliwe zwierzęta od wodopoju i terenów lowieckich. Wybudowanie trasy powoduje fragmentację przestrzeni, a izolowane ekosystemy są słabsze i narażone na ubożenie i zamieranie. Większe zwierzęta, mające siedliska w pobliżu drogi, oswojone są z hałasem i zbliżają się do szlaków komunikacyjnych, co naraża ich na śmierć w wyniku potrącenia (nie mówiąc przy tym o narażeniu zdrowia i życia człowieka). Hałas powoduje także zmianę zachowań ptaków i innych zwierząt (stany lękowe, zmiana siedlisk, zmniejszenie liczby składanych jaj, spadek mleczności krów). Niestety nie zdarza się, aby poza terenami zamieszkanymi przez ludzi budowano ekrany dźwiękochłonne, chroniące przyrodę i zwierzęta przed hałasem, mimo, że to właśnie na tych terenach bytują najczęściej dzikie zwierzęta. Codziennie na drogach ginie niezliczona ilość saren, jeleni, dzików, zajęcy, jeży, żab, ptaków (m.in. jaskółek) i wielu innych zwierząt, również domowych, takich jak koty i psy. 冈a druga grupa ginie, gdyż drogi biegną przez tereny zabudowane i zamieszkane przez ludzi. Nie jesteśmy w stanie określić, ile zwierząt ginie na drogach, ponieważ dowiadujemy się o nich wówczas, gdy uszkodzony zostaje samochód lub zginie człowiek.

5 http://rozmowy.onet.pl/artykul.html? I囚EM=1032882\&OS=34671 
Natomiast niewiele osób przejmuje się potrąconym zwierzęciem. Szczególnie niebezpieczny jest okres wzmożonych wędrówek oraz czas godów na terenach ostoi, przez które biegną trasy szybkiego ruchu. Nawet odgrodzenie drogi stalową siatką nie daje rezultatów, gdyż zbyt duże oczka siatki nie powstrzymują przed przejściem mniejszych zwierząt (np. królików, wiewiórek, jeży).

Nie stwierdzono natomiast żadnych negatywnych następstw oddziaływania dźwięków na rośliny, nawet o wysokich częstotliwościach.

\section{Zanieczyszczenie wód i ocena zmian stosunków wodnych}

Drogi i autostrady zalicza się do przedsięwzięć, które znacząco wpływają, zarówno na kształtowanie zasobów wód powierzchniowych i podziemnych, jak i na ich jakość. Stopień oddziaływania zależny jest od rodzaju inwestycji drogowej, stanu środowiska przyrodniczego, warunków geologiczno-hydrologicznych, topografii terenu itp. Do działań mających najbardziej negatywny wpływ na stosunki wodne podczas budowy i eksploatacji infrastruktury drogowej należą:

- przekształcenia rzek (regulacja koryta, zabudowa brzegów);

- przecięcia dolin rzecznych;

- zmiany ukształtowania terenu;

- likwidacja mokradeł i oczek wodnych;

- spływy wód z powierzchni dróg.

Substancje ropopochodne, pochodzące $z$ budowy (w małym stopniu) i eksploatacji infrastruktury drogowej stanowią dla wód i gleb poważne zagrożenie, ze względu na swoją toksyczność i rozpowszechnienie. Początkowo pokrywają one rośliny oraz wierzchnie warstwy gleby. Ich migracja zależy od właściwości chemicznych i fizycznych gleby, jej wilgotności oraz intensywności opadów atmosferycznych. W wyniku katastrofy drogowej, rozlane ropopochodne, w suchej warstwie gleby, przemieszczają się w głąb dość szybko (około $10 \mathrm{~cm}$ na godzinę), ponieważ suche cząstki glebowe (zwłaszcza próchnicze), szybko absorbują te substancje, zatrzymując jednocześnie jej migrację w warstwy głębsze. W glebie wilgotnej prędkość migracji maleje mniej więcej o połowę, ze względu na hydrofobowe właściwości ropopochodnych. Ponieważ woda, zawarta w glebie, pozostaje w ciągłym ruchu, stanowi tu ona nośnik zanieczyszczeń ropopochodnych. Składniki substancji ropopochodnych, zwłaszcza długołańcuchowe węglowodory są bardzo trwałe i nie ulegają biodegradacji. Długo więc, zalegają w środowisku wodno-glebowym i są trudne do usunięcia, przez co łatwo dostają się do organizmów żywych, powodując „skażenie” wszystkich ogniw łańcucha pokarmowego.

Okres zimowy w Polsce obfituje w zanieczyszczenie wód i gleb solą. Kierowcy oczekują od służb drogowych standardu „czarnej jezdni” przez cały okres zimy, co wymaga stosowania bardzo dużych ilości chlorku sodu i chlorku wapnia do posypywania zaśnieżonych dróg. Wraz z nadejściem sezonu roztopów sole do- 
stają się do przydrożnych gruntów, a następnie wód gruntowych powodując silną erozję gleby.

Istotne znaczenie przy projektowaniu, wykonawstwie i późniejszej eksploatacji dróg ma znajomość zjawiska kapilarności gruntów. „Wysoki stan wód gruntowych, spowodowany podsiąkaniem kapilarnym, sprzyja połączeniu wód infiltracyjnych (opadowych) z wodami gruntowymi i migracji do środowiska gruntowo-wodnego zanieczyszczeń wytwarzanych w procesie eksploatacji dróg"6. Kapilarność gruntu zależy głównie od jego uziarnienia. Woda kapilarna, zawarta pod powierzchnią gleby podsiąka wbrew siłom grawitacji: w górę, lub w bok, co sprzyja połączeniu się jej z zanieczyszczoną wodą opadową. Prędkość wzniosu kapilarnego jest większa im grunt jest bardziej gruboziarnisty (np. żwir) i większe są pory. Jednak woda podsiąka wtedy na mniejsze wysokości. W przypadku gruntu drobnoziarnistego (np. gliny, piaski gliniaste) woda osiąga najwyższy wznios kapilarny. Zagrożenie związane jest $\mathrm{z}$ tym, że woda kapilarna jest dobrym rozpuszczalnikiem soli i ma zdolność do transportowania rozpuszczonych soli i zawiesin. Powoduje to rozprzestrzenianie się zanieczyszczeń w glebie i wodach gruntowych.

Obecnie istnieje wiele metod stosowanych w zakresie wykrywania substancji ropopochodnych w środowisku gruntowo-wodnym. Ogólnie noszą one nazwę pomiarów atmogeochemicznych i polegają na poborze spod powierzchni gleby powietrza zawartego $\mathrm{w}$ przestrzeni porowej gruntu i jego analizie w celu określenia występujących w nim par węglowodorów ropopochodnych. Badania te mogą odbywać się w warunkach polowych $w$ aparatach pomiarowych (analizatorach, detektorach, czy rurkowych wykrywaczach gazu) lub w warunkach laboratoryjnych przy pomocy chromatografu gazowego, w którym można uzyskać największą dokładność. Na podstawie otrzymanych wyników określa się zanieczyszczenie gruntu, koncentrację węglowodorów, wielkość obszaru zanieczyszczonego czy kierunek migracji zanieczyszczeń. Dzięki tym badaniom można później określić lokalizację punktów monitorujących jakość wód podziemnych.

Wody powierzchniowe, sąsiadujące ze szlakami komunikacyjnymi, zawierają zwiększone ilości tlenków azotu, węglowodorów oraz związków metaloorganicznych. Szkodliwe substancje przedostają się do środowiska wodnego również na skutek opadania pyłów z powietrza. Powodują one zmianę barwy, smaku i zmętnienie, co wpływa ujemnie na jakość wody i jej przydatność do spożycia. Wzrost stężeń substancji zanieczyszczających ogranicza rozwój fauny i flory w zbiornikach wodnych. Ponieważ rozwój transportu w ostatnich latach nasilił się, stan czystości rzek polskich uległ znacznemu pogorszeniu. Zmniejszyła się długość odcinków rzek z wodami należącymi do I klasy czystości, a przybyło wód zaliczanych do klas wyższych oraz nieodpowiadających normom.

6 Portal Ochrony Środowiska GDDKiA: http://www.oos.pl/?id_str=69\&zaw=komponenty\&id_ kom $=$ artykuly\&id_art $=40$ 
Polska posiada stosunkowo niewielkie, na tle innych krajów, zasoby wodne, dlatego jednym $z$ priorytetowych działań powinno być racjonalne kształtowanie przestrzeni, aby zminimalizować ilość przedsięwzięć, które mogą powodować zmniejszenie naturalnej retencji krajobrazowej ${ }^{7}$. Zachowanie naturalności rzek, dolin i innych ekosystemów wodnych ma duze znaczenie dla zachowania i ochrony różnorodności biologicznej, a to z kolei uwarunkowane jest stabilnością poziomów i dobrą jakością wody. Można to osiągnąć dzięki zachowaniu warunków zasilania wód oraz poprzez ograniczenie do nich dopływu zanieczyszczeń. Zaburzenie stosunków wodnych, czyli zmiany poziomów wód gruntowych oraz eliminacja okresowego zalewania terenów powoduje w efekcie wypadanie lub ustępowanie gatunków wrażliwych na zmiany warunków siedliskowych, a nawet bezpośrednie zniszczenie siedlisk przyrodniczych.

Budowa autostrad to nie tylko wyasfaltowanie znacznej przestrzeni, ale także budowa tuneli, mostów, węzłów, rozjazdów, stacji benzynowych i MOP-ów (miejsc obsługi podróżnych). Roboty ziemne wykonywane w związku z budową drogi lub autostrady stają się często przyczyną zmian dotychczasowych stosunków wodnych, np. zakłócają ustalony spływ wód opadowych i gruntowych do naturalnych zbiorników. 囚owarzyszy im najczęściej osuszanie terenu, szczególnie niebezpieczne dla siedlisk podmokłych. Wyasfaltowanie dużych powierzchni terenu uniemożliwia zasilanie wód podziemnych przez wody opadowe, a spływy powierzchniowe zmniejszają przepuszczalność i retencję gleb, co podwyższa zagrożenie stanem powodziowym.

W czasie budowy drogi roślinność znajdująca się w jej najbliższym sąsiedztwie jest usuwana $w$ zasięgu wykonywanych robót ziemnych, a ponadto jest narażona na pogorszenie się warunków wegetacji w otoczeniu drogi. Zbiorniki bagienne stanowią ostoję wielu chronionych gatunków roślin i zwierząt, retencjonują wodę. \orfowiska kształtują poziom wód gruntowych w swym otoczeniu, oraz wilgotność powietrza i opady, a ich obniżanie może całkowicie zniszczyć torfowisko wraz z jego roślinnością. Ponadto może się zmniejszyć wydajność łąk i terenów uprawnych, w związku z obniżeniem poziomu wód gruntowych wywołanych budową drogi. Przez to naturalne zespoły roślin przekształcają się, kurczą się populacje i zasięg występowania lub nawet wymierają.

Wysokie stężenia substancji ropopochodnych w środowisku gruntowo-wodnym stanowią zagrożenie nie tylko dla fauny i flory, ale również dla samego człowieka. Środowisko to dostarcza człowiekowi odpowiednie ilości wysokokalorycznych składników odżywczych, witamin, substancji mineralnych, niezbędnych do budowy i właściwego funkcjonowania organizmu. Substancje ropopochodne i metale ciężkie zawarte $w$ wodzie i glebie kumulują się w tkankach roślin, spożywanych przez człowieka, co może spowodować rozwój miażdżycy i nowo-

$7 \quad$ www.gddkia.gov.pl 
tworów. Spożywanie ryb pochodzących z ekosystemów wodnych sąsiadujących $\mathrm{z}$ infrastrukturą drogową, gdzie stwierdzono podwyższone stężenia substancji ropopochodnych, grozi zatruciem pokarmowym. Kąpiele w rzekach, czy stawach w dużym stopniu zanieczyszczonych substancjami ropopochodnymi mogą powodować wystąpienie na skórze wysypki alergicznej w postaci pęcherzyków i rumieni. Pojenie zwierząt gospodarskich zanieczyszczoną wodą czy karmienie zielonką pochodzącą z terenów sąsiadujących z trasami komunikacyjnymi stwarza zagrożenie w postaci produktów mlecznych i mięsnych spożywanych przez ludzi. Przewlekłe narażenie na substancje ropopochodne prowadzi do często nieuleczalnych chorób układu pokarmowego (nowotwory, biegunki, białkomocz), zaburzeń hormonalnych, chorób układu krwionośnego (spadek stężenia hemoglobiny we krwi i niedotlenienie organizmu, spadek liczby erytrocytów, miażdżyca), choroby szpiku kostnego (zwłóknienie), zaburzenia układu nerwowego (bóle głowy, bezsenność, szum w uszach, pobudliwość nerwowa).

\section{Zanieczyszczenie gleb substancjami ropopochodnymi}

Ropa naftowa niszczy strukturę gruzełkowatą i koloidalną gleby, które odgrywają ważną rolę w kształtowaniu właściwości fizycznych, fizyko-chemicznych i biologicznych gleby oraz wywierają znaczny wpływ na stosunki powietrzno-wodne gleby. Zaburzone zostają jej właściwości wodne, powietrzne i cieplne oraz bilans jonowy, co pozbawia ją zdolności sorpcyjnych i niszczy życie biologiczne w środowisku glebowym. Następuje zubożenie trofizmu gleby, przez co gatunki wrażliwe na zmiany warunków siedliskowych ustępują lub wymierają. Skażenia w gruncie osiągają niekiedy bardzo wysoki poziom, często przekraczający dopuszczalne normy i sięgają znacznych głębokości. Jest to wynikiem tendencji paliw, olejów oraz ich uszlachetniaczy do migracji. Na podstawie art. 105 ust. 1 ustawy z dnia 27 kwietnia 2001 r. - Prawo Ochrony Środowiska (POŚ) - Minister Środowiska wydał rozporządzenie z dnia 9 września 2002 r. w sprawie standardów jakości gleby i ziemi, na podstawie których glebę lub ziemię uznaje się za zanieczyszczoną, jeśli stężenie co najmniej jednej substancji, wymienionej w załączniku do rozporządzenia, przekracza wartość dopuszczalną.

W czasie suszy substancje ropopochodne przemieszczają się w głąb ziemi z prędkością około $10 \mathrm{~cm} / \mathrm{h}$, gdyż suche cząstki gleby łatwo je absorbują, ale dzięki temu nie dopuszczają do migracji ropy do głębszych poziomów. W glebie wilgotnej prędkość ta maleje o połowę, ze względu na jej hydrofobowe właściwości. Woda stanowi w glebie główny nośnik ropy. Podlega ona działaniu sił elektrostatycznych, osmotycznych i kapilarnych. Pod wpływem siły ciężkości, woda opadowa staje się wodą grawitacyjną i spływa przez pory w głąb gruntu. \o właśnie woda grawitacyjna, wraz ze strukturą i składem mechanicznym gleby, decydują o szybkości migracji zanieczyszczeń. Substancje 
ropopochodne podlegają dalej ruchom wstępującym wody kapilarnej, co objawia się często ponownym wypłynięciem lekkich frakcji ropy na powierzchnię, w postaci tzw. "tęczowych kałuży”. Ulegają tu powolnemu wyparowaniu pod wpływem ruchu mas powietrza i promieniowania słonecznego oraz częściowo absorbowane są przez korzenie roślin. Cięższe frakcje ropy pozostają w gruncie. Im głębiej tym niższa jest temperatura gleby, dlatego w niższej temperaturze cięższe frakcje ropy zwiększają swoją gęstość, stając się mniej płynne i przenikliwe (niektóre nawet przechodzą z formy płynnej w stałą), co hamuje ich migrację na dalsze głębokości. Powoduje to wytworzenie w glebie warunków beztlenowych (anaerobowych) i zahamowanie wymiany gazowej pomiędzy atmosferą a powietrzem glebowym (nasycenie węglowodorami gazowymi: metanem, etanem, propanem i butanem). Woda opadowa również nie przenika swobodnie w głąb, lecz ulega stagnacji, a nadmierne zawilgotnienie gleby $i$ warunki beztlenowe przyczyniają się do szybkiego oglejenia gleby. W takim środowisku zanika życie biologiczne, a występują jedynie bakterie beztlenowe: siarkowodorowe, wodorowe, metanowe i redukujące żelazo ( $\mathrm{z}$ Fe trójwartościowego do Fe dwuwartościowego). Oczyszczanie biologiczne gleby przy pomocy naftofitów, możliwe jest tylko w górnych poziomach gruntu, na jego powierzchni. W głębszych warstwach, gdzie panują warunki beztlenowe rozwój bakterii degradujących ropę naftową jest zahamowany ze względu na ich właściwości aerobowe.

\section{Przekształcenia powierzchni ziemi i krajobrazu}

Przestrzeń przyrodnicza jest bardzo skomplikowanym systemem ekologicznym, w którym człowiek realizuje swoje indywidualne i cywilizacyjne potrzeby. Inicjatywa rozwoju wymaga jednak wykorzystania przestrzeni, której struktura często jest naruszana a funkcjonowanie zaburzane. Człowiek jest jedynie elementem ekosystemu, dlatego jego ingerencja powinna być ograniczona do minimum.

Przekształcenia powierzchni ziemi oraz degradacja ekosystemów są skutkiem coraz większej ingerencji człowieka w środowisko przyrodnicze. Realizacja planowanych inwestycji drogowych przyczynia się do bezpośredniego zniszczenia ekosystemów lub ich fragmentów (w tym również dna zbiorników i cieków wodnych) oraz siedlisk przyrodniczych i gatunków je zamieszkujących. Dodatkowym zagrożeniem dla dna zbiorników i cieków wodnych jest zahamowanie naturalnych przekształceń powierzchni ziemi, co powoduje wypadanie bądź ustępowanie gatunków wrażliwych na zmiany warunków siedliskowych. Izolacja populacji gatunków oraz przerywanie połączeń migracyjnych bezpośrednio zagrażające życiu zwierząt, przyczynia się do osłabienia zdolności przeżyciowych populacji (dryf genetyczny) i wypadania osobników na skutek kolizji drogowych. Często następuje odcięcie osobników od miejsc rozrodu, bazy pokarmowej i dostępno- 
ści do wody, przez co prawdopodobieństwo przeżycia całej populacji staje się jeszcze mniejsze.

Budowa trasy szybkiego ruchu wiąże się przeważnie z osuszaniem terenu, na którym wyznaczono lokalizację inwestycji. Przyczynia się to do zwiększenia, bądź zmniejszenia uwilgotnienia gleby w miejscu prac drogowych i na obszarach sąsiadujących oraz może wywołać okresowe zalewanie wcześniej suchych terenów, co również powoduje zmiany w populacjach gatunków wrażliwych. Równocześnie ubożeje trofizm (stan zasobów pokarmowych) gleb, przez co gatunki roślin wymagające żyznych siedlisk oraz uzależnione od nich zwierzęta lądowe ustępują z tych terenów.

Późniejsza eksploatacja trasy niesie za sobą podwyższenie temperatury gleby i zmiany mikroklimatu w strefie położonej najbliżej nawierzchni drogowej, co stanowi presję dla siedlisk i gatunków o ograniczonej tolerancji zmian temperatur. Zmiany warunków mikroklimatycznych następują również w wyniku emisji i imisji pyłów i zanieczyszczeń chemicznych, prowadzących do skażenia i erozji gleb. Nie bez znaczenia jest także spływ i infiltracja zanieczyszczeń z nawierzchni drogowych, które powodują zmiany w strukturze i składzie chemicznym okolicznych gleb. Nasypy drogowe, mosty, czy ekrany akustyczne zamocowane wzdłuż trasy przyczyniają się do zmian lokalnej cyrkulacji mas powietrza.

Zaburzenia w przestrzeni negatywnie wpływające na behawior zwierząt, wiążą się również z wytwarzaniem na trasach sztucznych źródeł światła, zarówno przy pracach budowlanych, jak i podczas eksploatacji infrastruktury. Oświetlenie nadjeżdżającego samochodu wabi zwierzęta, oślepia je i dezorientuje, przez co ich śmiertelność w wyniku kolizji drogowych nadal stanowi poważny problem dla planistów i architektów.

Wszystkie wymienione powyżej zagrożenia powinny uświadomić powagę niebezpieczeństwa i spowodować, że autostrady będą prowadzone poza obszarami chronionymi. Jednak biorąc pod uwagę polskie realia jak i zbyt małą ilość tras szybkiego ruchu, powinny być one tak umiejscawiane, aby ich oddziaływanie na środowisko było jak najmniejsze.

Przekształcanie naturalnych układów przestrzennych ma również wpływ na człowieka. Krajobraz wpływa na jego doznania wizualne i emocjonalne. Piękno i atrakcyjność zależy od wielu czynników, m.in.: rzeźby terenu, szaty roślinnej, obecności obiektów urbanizacyjnych itp. \ylko krajobrazy nieprzekształcone jeszcze przez człowieka oraz częściowo przekształcone z zachowaniem cennych elementów przyrodniczych, stanowią dla niego ostoję i atrakcję turystyczną. Jednak działalność antropogeniczna rozszerza się coraz bardziej, dlatego priorytetem powinny być przedsięwzięcia, mające na celu zachowanie - w stanie nienaruszonym - terenów cennych przyrodniczo.

Coraz gęstsza sieć infrastruktury liniowej w Polsce zaburza ład przestrzenny i przyczynia się do dysharmonii w krajobrazie. Często trasy komunikacyjne bie- 
gną na terenach o cennych walorach estetycznych i przyrodniczych - przechodzi przez lasy i mokradła, przecina szlaki migracji zwierząt. Dopiero w ostatnich latach zrozumiano powage sytuacji i zagrożenie, jakie niesie za sobą rozcinanie krajobrazu infrastrukturą liniową. Człowiek, żyjący w u miastach poszukuje coraz częściej miejsc odpowiednich do psychicznego odpoczynku od cywilizacyjnego zgiełku. Đereny rekreacyjne, które nie uległy jeszcze ludzkiej ekspansji, stanowią coraz cenniejszy skarb środowiska i są bardziej doceniane i szanowane.

\section{Szkodliwość infrastruktury drogowej dla zwierząt}

Infrastruktura drogowa oddziałuje wszechstronnie na elementy środowiska przyrodniczego, powodując zagrożenie dla różnorodności biologicznej, w szczególności skupiając się na zwierzętach. Przede wszystkim wynika ono z podziału obszarów siedliskowych (fragmentacja siedlisk) oraz przerywania ciągłości korytarzy migracyjnych. Negatywne oddziaływanie budowy i eksploatacji dróg dotyka przede wszystkim kompleksy leśne, łąkowe i obszary wodno-błotne o dużych powierzchniach. Dalsza rozbudowa sieci dróg ekspresowych i autostrad, spowoduje presję na najcenniejsze siedliska przyrodnicze, a skutki ekologiczne odczuwalne będą na obszarach o największych walorach przyrodniczych (np. w północnej Polsce i w Karpatach), w większości podlegających ochronie prawnej, w ramach sieci Natura 2000.

Poszczególne gatunki zwierząt posiadają różne wymagania związane z przestrzenią - wynikają one z wielkości zamieszkiwanych areałów osobniczych oraz z intensywności i dystansu przemieszczania się. Największe wymagania względem przestrzeni życiowej mają w Polsce duże ssaki drapieżne, np. ryś, wilk, niedźwiedź, dlatego ich populacje są wyjątkowo zagrożone (terytorium jednej watahy wilczej to obszar o wielkości około $250 \mathrm{~km}^{2}$, a terytorium jednego rysia to $100-200 \mathrm{~km}^{2}$ ). Dużych przestrzeni potrzebują także ssaki kopytne np. żubr (terytorium ok. 90 $\mathrm{km}^{2}$ ), czy jeleń (terytorium ok. $10-30 \mathrm{~km}^{2}$ ). Areały osobnicze ssaków średnich i małych (np. saren, lisów, zajęcy czy borsuków) nie przekraczają kilku km².

Możliwość swobodnego przemieszczania się osobników stanowi podstawę dla normalnego funkcjonowania większości gatunków zwierząt. Umożliwia im zaspokajanie podstawowych potrzeb życiowych: zdobywanie pokarmu, szukanie schronienia, wymianę genetyczną i rozród. Przemieszczanie zwierząt może odbywać się $\mathrm{w}$ formie:

- migracji dobowych - w ciągu dnia i nocy w granicach własnego areału osobniczego i poza jego granicami;

- migracji sezonowych - w cyklu rocznym, w różnych porach roku, najczęściej poza obszarem własnego areału osobniczego;

- wędrówek - poza obszar własnego areału osobniczego, w celu znalezienia i zajęcia nowych terytoriów lub partnerów do rozrodu. 
Największy dystans migracji dobowych posiadają duże ssaki drapieżne np. wilk, który w ciągu doby potrafi przemieścić się na odległość $65 \mathrm{~km}$. Najdłuższe migracje sezonowe odbywają ptaki, płazy i ssaki roślinożerne. Najdłuższe wędrówki natomiast, dotyczą w Polsce żubrów, wilków i łosi. Jednak zwierzęta, które posiadają największe wymagania odnośnie przestrzeni życiowej, są najbardziej kolizyjne na obszarach infrastruktury drogowej, dlatego też są one najbardziej zagrożone.

Formy i skutki negatywnego wpływu na świat przyrody są różnorodne:

- utrudnienie przemieszczania się zwierząt i nasion roślin w poprzek dróg;

- zniszczenie i degradacja siedlisk w obrębie pasa drogowego oraz kumulacja zanieczyszczeń, hałas i drgania w strefie bezpośredniego sąsiedztwa z trasą;

- zabijanie zwierząt w wyniku kolizji drogowych;

- ekspansja gatunków obcych i synantropijnych na nowe tereny;

Oddziaływania te spowodują degradację rzadkich i zagrożonych siedlisk, zamieranie lokalnych populacji fauny i flory oraz wzrost tempa wymierania gatunków rzadkich i zagrożonych.

Negatywne oddzialywanie planowanych dróg na korytarze migracyjne zwierząt wynika z tworzenia tzw. barier ekologicznych, których efektem jest ograniczenie lub całkowite zahamowanie możliwości przemieszczania się gatunków w poprzek drogi. Spowodowane jest to przerwaniem ciągłości kompleksów leśnych na skutek zajęcia terenu przez pas drogowy i towarzyszącą mu infrastrukturę (stacje benzynowe, motele, zajazdy itp.) Nie bez znaczenia są również ogrodzenia ochronne, prowadzone wzdłuż drogi, stanowiące barierę fizyczną dla przemieszczających się zwierząt. Wysoka koncentracja zanieczyszczeń chemicznych w strefie bezpośredniego sąsiedztwa z pasem drogowym oraz hałas i drgania odstraszają zwierzęta, posiadające siedliska i terytoria w pobliżu trasy.

Barierę ekologiczną określa się obecnie, jako kompleksowy efekt działania śmiertelności, fizycznych ograniczeń, przekształceń i oddziaływań, które ograniczają danemu gatunkowi możliwości przekraczania drogi i sąsiadującej z nią infrastruktury. Obecność barier prowadzi do podziału siedlisk na mniejsze płaty (fragmentacja siedlisk), co w konsekwencji utrudnia przemieszczanie się gatunków je zamieszkujących (izolacja siedlisk).

Na tworzenie barier migracyjnych i ich stopień oddziaływania wplywa:

- natężenie ruchu pojazdów na drodze - drogi o natężeniu ruchu powyżej 1000 pojazdów/dobę, stanowią utrudnienie w przemieszczaniu się zwierząt, a drogi o natężeniu ruchu powyżej 10000 pojazdów/dobę, stanowią już nieprzekraczalną barierę;

- konstrukcja techniczna drogi - zbyt duża wysokość nasypu drogowego oraz stosowanie ogrodzeń ochronnych, utrudniają przemieszczanie zwierząt dużych i uniemożliwiają przemieszczanie się zwierząt średnich i małych; 
- lokalizacja drogi - negatywny wpływ barier zależy od wrażliwości siedlisk i wartości przyrodniczej terenów, przez które przebiega infrastruktura liniowa.

Obecnie najważniejszym skutkiem oddziaływania barier ekologicznych jest przerywanie ciągłości korytarzy migracyjnych o znaczeniu kontynentalnym (paneuropejskim) oraz ingerencja człowieka w najcenniejsze obszary przyrodnicze objęte ochroną prawną w ramach sieci Natura 2000. Konflikty dotyczą zarówno istniejącej sieci drogowej, jak i odcinków planowanych.

Najbardziej konfliktowe odcinki dróg, pod względem barier ekologicznych to:

- autostrada A1, odcinek: granica woj. pomorskiego-Czerniewice;

- autostrada A2, odcinek: Nowy 区omyśl-Świecko;

- autostrada A18; odcinek: Olszyna-Golnice;

- droga ekspresowa S-3, odcinek: Lipiany-Nowa Sól;

- droga ekspresowa S-7, odcinek: Spytkowice-Chyżne;

- droga ekspresowa S-8, odcinek: Białystok-Augustów;

- droga ekspresowa S-19, odcinek: Krosno-Barwinek;

- droga ekspresowa S-69, odcinek: Milówka-Zwardoń.

\section{Podsumowanie}

Budowa dróg szybkiego ruchu stanowi największą ingerencję człowieka w układy ekologiczne środowiska naturalnego. Wywierają one znaczny wpływ na rozmieszczenie poszczególnych gatunków zwierząt oraz ich warunki siedliskowe. Rozbudowa infrastruktury drogowej pochłania połacie ziemi, niszcząc siedliska i powodując degradację terenu nie tylko w miejscu budowy, lecz również na terenach poboru kruszyw, czy składowania materiałów i maszyn. W otoczeniu budowanej i później eksploatowanej autostrady następuje zmiana warunków siedliskowych. Zmiany stosunków wodnych i uwilgotnienia gleb, budowa nasypów bądź równanie terenu oraz wszelkie zanieczyszczenia, hałas i wibracje, powodują zmiany mikroklimatyczne, a co za tym idzie - zmiany w rozmieszczeniu populacji gatunków roślin i zwierząt. Fragmentacja przestrzeni przez infrastrukturę liniową odcina osobniki od miejsc rozrodu i bazy pokarmowej. W rezultacie populacje stają się coraz mniejsze i narażone na wyginięcie przez niską reprodukcję i kolizje z pojazdami. Następuje spadek bioróżnorodności, a tereny sąsiadujące z drogą zasiedlane są przez gatunki synantropijne o niewielkich wymaganiach siedliskowych. Rezultatem tych procesów są trwałe zmiany warunków przyrodniczych i krajobrazu. 


\title{
BIBLIOGRAFIA
}

ENGEL Z., Ochrona środowiska przed drganiami i hałasem, Wydawnictwo Naukowe PWN, wyd. II popr., Warszawa 2001.

Gronowicz J., Ochrona środowiska w transporcie ladowym, Wyd. I囚E, Radom 2004.

JęDrzejewski W., Nowak S., Kurek R., Mrseajek R., Stachura K., Zwierzęta a drogi. Metody ograniczania negatywnego wplywu dróg na populacje dziko żyjących zwierząt, Zakład Badania Ssaków PAN, Białowieża 2004.

Portal internetowy Generalnej Dyrekcji Dróg Krajowych i Autostrad: http://www.gddkia.gov.pl

Portal internetowy Ministerstwa Środowiska: http://www.mos.gov.pl

Portal internetowy Ministerstwa Infrastruktury: http://www.mt.gov.pl

Portal internetowy Ministerstwa Gospodarki: http://www.mg.gov.pl

\section{The assessment of impact of the construction and exploitation roads to abiotic and biotic factors of environment}

\author{
SUMMARY
}

The expansion of the road network in Poland and in world constitutes a considerable risk for the natural environment. This article is showing the most important effects of road investments, for example: pollutants of atmospheric air, the noise and vibrations, pollutants of waters and soils, the fragmentation of the space and the decline of the landscape. Everything is leading it for destroying the environment in which we live. Describing all threats to the environment with themselves a structure and an exploitation of roads are bringing which, is practically impossible. The man in the last years very much is interfering in the nature, instead of to protect it for next generations. Therefore designers and entrepreneurs should concentrate on eliminating negative effects of construction and the more late exploitation of roads and for improvement in their technical state. 